\title{
THE EFFECT OF RAMADAN MONTH ON STOCK RETURN AND VOLATILITY OF A SHARIA-BASED INDEX
}

\author{
Arief Rahmatullah \\ Management Department, University of Surabaya, Indonesia \\ Putu Anom Mahadwartha* \\ Management Department, University of Surabaya, Indonesia \\ anom@staff.ubaya.ac.id \\ Endang Ernawati \\ Management Department, University of Surabaya, Indonesia \\ endangernawati@staff.ubaya.ac.id
}

*Corresponding author

\begin{abstract}
This study aims to examine the effect of a religious-related calendar anomaly, namely Ramadan, on stock return and volatility of a Sharia-based index in Indonesia. This study used the GARCH $(\mathrm{p}, \mathrm{q})$ method and linear regression to examine the effect of Ramadan on stock returns and volatility, with Ramadan as a dummy variable. This study results show that Ramadan month has a significant positive effect on stock returns, or it can be said that an anomaly occurs during Ramadan month. Meanwhile, volatility during Ramadan month is negative and not significant. This study also exercised a T-test to support the GARCH regression $(p, q)$ and linear regression results. The t-test results show that the average return during Ramadan is higher than in other months. Meanwhile, the average volatility during Ramadan is lower than in other months.

Keywords: Ramadan effect, seasonal anomaly, stock yield, volatility, GARCH $(p, q)$
\end{abstract}

\section{INTRODUCTION}

Ramadan month is a holy month for Muslims. During the month, Muslims around the world fast for thirty days. This Ramadan anomaly can occur in Muslim majority countries like Indonesia due to significant differences in returns compared to the other months. The month of Ramadan is an interesting phenomenon from an economic point of view. Besides, the month of Ramadan is fascinating because it is an annual event in the Hijri calendar, which is based on the Lunar calendar. When Muslim society is required to increase worship intensity and economic activities slow down due to reduced working hours in several sectors, spending on basic needs and consumption increases (Al-Khazali et al., 2017). This increased spending may result in significant differences in returns during Ramadan compared to the other months. As a result, investors feel optimistic about buying more stocks. This is also supported by Bialkowski et al.'s 
(2012) study, which suggests that the Ramadan effect is caused by investor psychology and thereby affects investment decisions (Rosen \& Wu, 2004 in (Bialkowski et al., 2012). The increase in consumption is followed by an increase in electricity consumption, especially during the night, as a result of an increase in night religious activities by the Muslim society. The month of Ramadan can also affect stock volatility. During Ramadan, volatility tends to decrease because Muslims reduce trading activities and focus more on worship activities (AlKhazali et al., 2017). In addition, stock trading activities or margin trading may be avoided because it is related to the use of interest, which is strictly prohibited in Islam (Al-Ississ, 2010).

Bialkowski et al. (2012) examine investor sentiment and stock returns during Ramadan month. This study investigates stock returns during Ramadan for 14 Muslim countries over the 1989 to 2007 period and uses stock return as the dependent variable and Ramadan dummy, return_world, and return_world_lag as independent variables. This study also examines several calendar anomalies such as the January, Turn-of-the-week, and Halloween effects and exercises abnormal returns and linear regression methods. The study is conducted by dividing into three (3) groups, where Group 1 includes 14 countries that have a Muslim population above $50 \%$, Group 2 consists of 14 countries that have a Muslim population between $5 \%$ and $50 \%$, and Group 3 comprises 39 countries that have a Muslim population of less than 5\%. The study results reveal that during Ramadan, Group 1 has a significant positive effect on stock returns. Meanwhile, Groups 2 and 3 are significantly positive. However, the study also reveals that the return_world and return_world_lag variables are significantly positive in all groups.

Al-Ississ (2015) investigates the effect of holy days on stock returns, mainly focuses on a Muslim holy day, Ramadan. This study dataset comes from firms listed in the stock exchanges of 10 Muslim countries from 1 January 1995 to 31 August 2012. The research uses stock return as the dependent variable and Ramadan as the independent variable. It reveals that stock returns during Ramadan have a negative and not significant effect. The researcher also examines stock returns among countries where he finds that returns on Ramadan's last five odd days are positive in 6 out of the 10 countries, negative in Turkey, and not significant in Morocco, Malaysia, and Qatar. Furthermore, this study also regresses stock returns during Ramadan by separating the countries where stock returns have a negative and not significant effect, like in Indonesia, Malaysia, and Qatar. Meanwhile, Egypt, Jordan, Pakistan, and Kuwait have a positive and significant stock return, and Ramadan month has a negative but significant effect in Morocco, Saudi Arabia, and Turkey. Furthermore, the study also analyzes how it affects the MSCI index, and its results reveal that the effect of Ramadan on MSCI is significantly positive.

Al-Khazali et al. (2017) analyze how Ramadan religious activities affect volatility and stock returns. The study uses volatility and stock return as dependent variables and Ramadan as the independent variable and daily data on stock market indices of 15 Muslim countries from 31 December 2005 to 31 December 2015. Applying an ARMAX-GARCH model, this study finds 
significant negative volatility during Ramadan in Abu Dhabi, Bahrain, Dubai, Egypt, Indonesia, Oman, and Pakistan. Besides volatility, researchers also study the effect of religious activities (Ramadan) on stock returns. The results of this study are significantly positive in Dubai. While Abu Dhabi, Bahrain, Egypt, Jordan, Kuwait, Morocco, Oman, Pakistan, Qatar, Tunisia, and Turkey are significantly positive. The rest, Indonesia, Malaysia, and Saudi Arabia are significantly negative. In addition, the researchers use the MSCI index to examine its effect on the world market index, and the results reveal significant positive returns in Indonesia, Abu Dhabi, Egypt, Jordan, Kuwait, Malaysia, Oman, Qatar, Saudi Arabia, and Turkey.

Lai \& Windawati (2017) investigate risk, return, and liquidity during Ramadan in the Indonesian and Malaysian stock markets. This study uses data from Jakarta Composite Index (JII) and Jakarta Islamic Index (JII) for the Indonesian Stock Exchange and FTSE Bursa Malaysia KLCI (FBMKLCI) and FTSE Bursa Malaysia Hijrah Sharia (FBMHS) for the Malaysian stock market. The study covers the period from 20 May 2010 to 30 November 2015 and applies the asymmetric GARCH (GJR-GARCH) and the GARCH-in-mean (GARCH-M) models. It uses risk, returns, and liquidity as dependent variables and Ramadan as the independent variable. The results of this study stipulate that stock return during Ramadan in Indonesia is positive and not significant for JII and JCI, and volatility during Ramadan in Indonesia is positive and significant for JII and JCI. In the Malaysian stock market, return during Ramadan is positive and not significant and volatility is positive and not significant. Except for the JII, the other three indices display higher liquidity during Ramadan.

\section{RESEARCH METHOD}

This study is basic research, which refers to a study to develop further research that has been done previously. Based on the approach, this research is quantitative. Based on the purpose, this research is a causal type because it was conducted to examine the effect of the independent variable (Ramadan) on the dependent variables (stock return and volatility) on stocks included in the Indonesian Sharia Stock Index (ISSI index) from 15 November 2012 - 20 September 2017 (1434-1438H).

Stock return is the result of total gain or loss earned from investing in stocks that consist of capital gain (loss) plus dividend for the company that distributes it. Stock returns during the study period were calculated using the natural logarithm of the daily closing stock price (adjusting closing price):

$R_{t}=\ln \left(\frac{P t}{P t-1}\right)$

Where:

$R_{t} \quad=$ Stock's actual return on day $\mathrm{t}$

$P_{t} \quad=$ stock price on day $\mathrm{t}$

$P_{t-1} \quad=$ stock price on day $\mathrm{t}-1$ 
After calculating stock returns using the natural logarithm, the average return during Ramadan and non-Ramadan months was also calculated. The average stock return was calculated using stock return data that has been calculated using Equation (1), which then calculates the average return during Ramadan and nonRamadan months. In calculating the average daily stock return per month, this study uses the following formula:

$\mathrm{R}_{\mathrm{it}}=\sum \frac{n}{t}={ }_{1} R_{i} / n$

Where:

Rit $\quad=\mathrm{i}$ stock return in a specific period

$\mathrm{Ri} \quad=\mathrm{i}$ daily stock return

$\mathrm{n} \quad=$ Number of observation days

Volatility is the degree of dispersion of stock return due to market changes and is a systematic risk. In this study, volatility was calculated using the standard deviation. The standard deviation formula is as follows:

$S=\sqrt{\frac{\sum_{\overline{i=1}}^{n}(x i-\bar{x})^{2}}{n-1}}$

where:

$\mathrm{S} \quad=$ Standard deviation

$\mathrm{X}_{\mathrm{i}} \quad=\mathrm{i}$-th $\mathrm{x}$ value

$\overline{\mathrm{x}} \quad=$ mean value

$\mathrm{n} \quad=$ The size of the number of data

Ramadan effect or Ramadan anomaly refers to an anomaly that occurs during, before, and after Ramadan. In this study, Ramadan is a dummy variable. If the $\mathrm{t}$-th time is Ramadan, then it takes the value 1, and if other months or nonRamadan months, then it takes the value 0 .

The MSCI Index (Morgan Stanley Capital International) is an index formed by Morgan Stanley Capital International to measure world market performance. The world variable is used to determine its effect on the world. In this study, $R_{w . t i s}$ the world variable and $R_{w . t-1}$ is worldlag1 that is the control variable. The MSCI index return during the period under study was calculated using the natural logarithm as follows:

$R_{t}=\ln \left(\frac{P t}{P t-1}\right)$

After calculating the MSCI index return using the natural logarithm, then the average return of the MSCI index during Ramadan and non-Ramadan months was calculated. In calculating the average daily MSCI index return per month, this study uses the following formula: 
$\mathrm{R}_{\mathrm{it}}=\sum \frac{n}{t}={ }_{1} R_{i} / n$

After calculating the MSCI index return, the volatility of the MSCI index was calculated using the standard deviation. The standard deviation formula is as follows:

$S=\sqrt{\frac{\sum_{i=1}^{n}(x i-\bar{x})^{2}}{n-1}}$

The type of data used in this research is secondary data in the form of daily stock price data for stocks included in the ISSI (Indonesian Sharia Stock Index) index for the 15 November 2012 - 20 September 2017 period. The secondary data of this study used daily stock price data from the Yahoo Finance website (http:// /finance.yahoo.com) and investing (http://investing.com). The level of measurement used in this study is the ratio and nominal scales. The ratio scale is used in this study because the unit of measure describes the actual value of the research object being measured that can be calculated by mathematical operations. Meanwhile, the nominal scale is used in this study because it uses a dummy variable.

The target and population characteristics used in this study were stocks listed on the Indonesia Stock Exchange and the population characteristics in this study were stocks included in the ISSI index (Indonesian Sharia Stock Index) over the period 15 November 2012 - 20 September 2017 or 1434-1438H and not suspended during the estimation period. In addition, the stock is consistently included on the ISSI index (Indonesian sharia stock index) and has the largest capitalization.

Table 1

Ramadan month Calendar over period 2013 - 2017 (1434 - 1438H)

\begin{tabular}{|c|c|c|c|c|}
\hline Year & AD Ramadan & Ramadan & $\begin{array}{l}\text { Number of } \\
\text { trading days }\end{array}$ & AD Trading dates \\
\hline $\begin{array}{c}2013 \\
(1434 \mathrm{H})\end{array}$ & $\begin{array}{c}10 \text { Juley - } 8 \\
\text { August }\end{array}$ & $\begin{array}{c}1 \text { Ramadan - } 29 \\
\text { Ramadan }\end{array}$ & 18 days & 10 July- 5 August \\
\hline $\begin{array}{c}2014 \\
(1435 \mathrm{H})\end{array}$ & 29 June - 28 July & $\begin{array}{c}1 \text { Ramadan - } 27 \\
\text { Ramadan }\end{array}$ & 18 days & 30 June - 24 July \\
\hline $\begin{array}{c}2015 \\
(1436 \mathrm{H})\end{array}$ & 18 June - 17 July & $\begin{array}{c}1 \text { Ramadan - } 29 \\
\text { Ramadan }\end{array}$ & 20 days & 18 June - 15 July \\
\hline $\begin{array}{c}2016 \\
(1437 \mathrm{H})\end{array}$ & 6 June - 5 July & $\begin{array}{c}1 \text { Ramadan - } 30 \\
\text { Ramadan }\end{array}$ & 20 days & 6 June - 1 July \\
\hline $\begin{array}{c}2017 \\
(1438 \mathrm{H})\end{array}$ & 27 May - 24 June & $\begin{array}{l}1 \text { Ramadan } 29 \\
\text { Ramadan }\end{array}$ & 18 days & 29 May - 22 June \\
\hline
\end{tabular}

(Source: Habib,nd.)

The data processing method used was the GARCH $(\mathrm{p}, \mathrm{q})$ model regression and linear regression. GARCH regression $(p, q)$ was used to test the effect of Ramadan month on stock returns. Meanwhile, linear regression was used to test the effect of Ramadan month on volatility. GARCH is a model developed from 
the ARCH model by Bollerslev (Annila \& Kristanti, 2015). In this study, the Ramadan variable is a dummy variable. The equations used in this study are as follows:

Conditional Mean Equation:

$R_{t}=a_{0}+a_{1} R_{w . t}+a_{2} R_{w, t-1}+a_{3}$ DRamadan $_{t}+\varepsilon_{t}$

where:

$\mathrm{R}_{\mathrm{t}} \quad=$ Return in month $\mathrm{t}$

$\mathrm{R}_{\mathrm{w} . \mathrm{t}} \quad=$ Return world in month $\mathrm{t}$

$\mathrm{R}_{\mathrm{w} . \mathrm{t}-1} \quad=$ Return world in month $\mathrm{t}-1$

DRamadan $_{\mathrm{t}}=$ Ramadan dummy variable

Conditional Variance:

$\sigma_{t}^{2}=\omega+\alpha \varepsilon_{t-1}^{2}+\beta \sigma_{t-1}^{2}$

where:

$\sigma_{\mathrm{t}}^{2} \quad=$ Conditional Variance

$\alpha \varepsilon^{2}{ }_{\mathrm{t}-1} \quad=\mathrm{ARCH}(\mathrm{p})$

$\beta \sigma_{\mathrm{t}-1}^{2} \quad=\mathrm{GARCH}(\mathrm{q})$

Before performing regression using the GARCH (p,q) model, it is necessary to test for normality, stationarity, autocorrelation, heteroscedasticity, and ARCHLM. Testing the effect of Ramadan month on volatility cannot use the GARCH $(p, q)$ regression model because the residual reflects changes in the worldlag1 variable and the variable affecting stock returns (dependent variable). Meanwhile, the volatility variable is calculated from the standard deviation of return so that volatility cannot use the GARCH $(p, q)$ model. The equations used in this study are:

$V O L_{i t}=\alpha+\beta 1 . W_{O R L D}+\beta 2$. WORLD $_{t-1}+\beta 3 . D R A M A D A N_{t}$

where:

VOL $_{i t} \quad=$ Stock Volatility in period $\mathrm{t}$

WORLD $_{\mathrm{it}} \quad=$ Standard deviation of msci index in period $\mathrm{t}$

WORLD $_{\mathrm{t}-1}=$ Standard deviation of msci index in period $\mathrm{t}-1$

DRamadan $=$ Ramadan dummy variable

$\alpha \quad=$ constant coefficient

$\beta \quad=$ regression coefficient

Before performing linear regression, it is necessary to test the classical assumptions, namely normality, multicollinearity, autocorrelation, heteroscedasticity, and Chow \& Haussmann.

\section{RESULTS AND DISCUSSION}

The objects used in this research were all companies listed on the Indonesia Stock Exchange (IDX). This study used stocks that are consistently included in the ISSI index over the period 15 November 2012 - 20 September 2017 (1434-1438H). of 
the stocks that are consistently in the ISSI index and have the largest capitalization, it can be found that 43 companies fulfilled the criteria and can be used as the objects.

Table 2

Descriptive Statistics of Return, World \& Worldlag1 Variables

\begin{tabular}{lrrr}
\hline & \multicolumn{1}{c}{ RETURN } & WORLD & WORLDLAG1 \\
\hline Mean & 0.000304 & 0.000358 & 0.000359 \\
Median & 0.000000 & 0.000620 & 0.000620 \\
Maximum & 0.041470 & 0.002920 & 0.002920 \\
Minimum & -0.035310 & -0.003740 & -0.003740 \\
Std. Dev. & 0.006458 & 0.001343 & 0.001344 \\
Skewness & 0.289586 & -0.729338 & -0.726918 \\
Kurtosis & 6.786527 & 3.701924 & 3.699895 \\
Jarque-Bera & 1576.760000 & 281.587700 & 279.767000 \\
Probability & 0.00000 & 0.00000 & 0.00000 \\
Sum & 0.784800 & 0.923730 & 0.925050 \\
Sum Sq. Dev. & 0.107538 & 0.004648 & 0.004653 \\
Observations & 2579 & 2579 & 2579 \\
\hline (Source: Data processing using EViews 8 software) &
\end{tabular}

Table 2 exhibits that the number of observations in this study was 2579 . The maximum value for the return variable was obtained by the IIKP issuer (PT Inti Agri Resources Tbk) in December 2015 or Rabiulawwal 1437 Hijriah with 0.041470 and the minimum value on the return variable was obtained by the ADHI issuer (PT Adhi Karya (Persero) Tbk.) in August 2013 or the month of Shawwal 1434 Hijri with -0.035310 . The maximum value for the world variable and worldlag1 was obtained in November 2012 or the month of Muharram 1434 Hijriah with 0.00292 and the minimum value for the world variable and worldlag1 was obtained in December 2015 or the month of Rabiulawwal 1437 with 0.00374 . The return variable of 0.006458 is the highest standard deviation and the worldlag1 variable of 0.001343 is the lowest. The higher the value of the standard deviation, the greater the variable's range of values.

Table 3

Descriptive Statistics of Volatility, World \& Worldlag1 Variables

\begin{tabular}{lrrr}
\hline & \multicolumn{1}{c}{ VOL } & \multicolumn{1}{c}{ WORLD } & WORLDLAG1 \\
\hline Mean & 0.025162 & 0.006195 & 0.006224 \\
Median & 0.022400 & 0.005790 & 0.005790 \\
Maximum & 1.025740 & 0.015760 & 0.015760 \\
Minimum & 0.000000 & 0.002680 & 0.002680 \\
Std. Dev. & 0.023486 & 0.002449 & 0.002421 \\
Skewness & 30.821910 & 1.426966 & 1.476312 \\
Kurtosis & 1300.667 & 5.805216 & 5.958747 \\
Jarque-Bera & 178000000 & 1692.831000 & 1846.955000 \\
Probability & 0.00000 & 0.00000 & 0.00000 \\
Sum & 63.83556 & 15.71693 & 15.79089 \\
\hline
\end{tabular}




\begin{tabular}{lrrr}
\hline & & & (Cont.) \\
\hline VOL & \multicolumn{1}{c}{ WORLD } & WORLDLAG1 \\
Observations & 1.398833 & 0.015213 & 0.014865 \\
\hline
\end{tabular}

(Source: Data processing using EViews 8software)

Table 3 is a descriptive statistic of the VOL (volatility), world, and worldlag1 variables. The number of observations in the study of the effect of Ramadan on volatility was 2537. The maximum and minimum values were obtained by the VOL (volatility) variable of 1.025740 and 0.000000 . Before performing regression using the GARCH $(p, q)$ method, it is necessary to test for normality, augmented dicky fuller (ADF), autocorrelation, heteroscedasticity, and ARCH-LM.

Normality test was conducted using the EViews 8 software by looking at the Jarque-Bera test results. The data tested for normality is the dependent variable, namely stock return. The following are the normality test results:

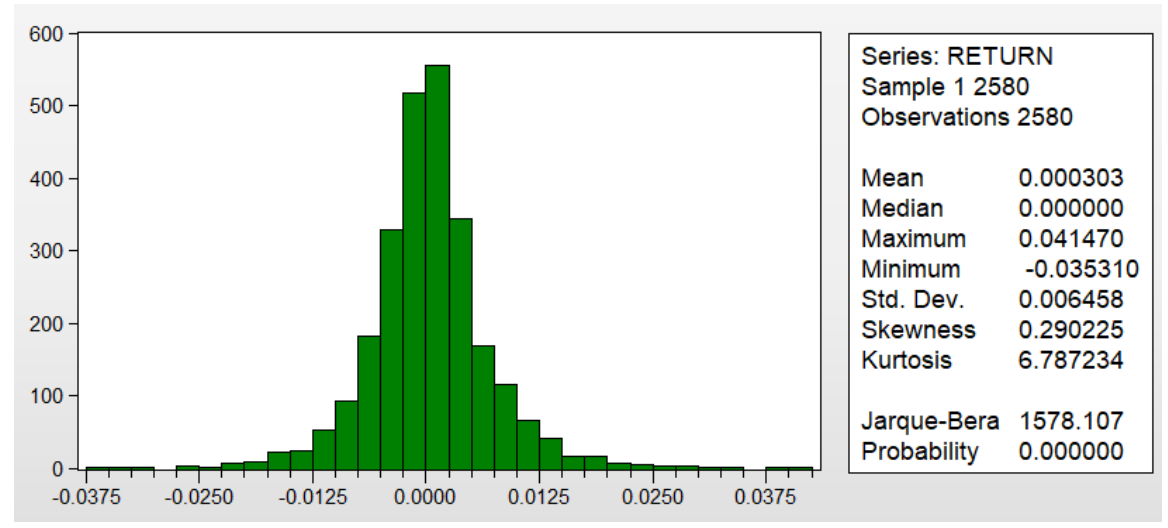

Figure 1

Normality Test of Dependent Variable

(Source: Data processing using EViews 8 software)

Stationary data have the same mean, variance, and autocovariance at any time the data is formed. In table 4 , it can be seen that the stock return variable is stationary as shown in the t-statistic, which is smaller than the t-critical of 50.10702. The following are the stationarity test results:

Table 4

Augmented Dickey-Fuller Test Statistic (ADF) test on the Stock Return variable

\begin{tabular}{|c|c|c|c|}
\hline \multicolumn{2}{|c|}{ ADF Test } & t-Statistic & Prob.* \\
\hline \multicolumn{2}{|c|}{ Augmented Dickey-Fuller Test Statistic } & -50.10702 & 0.0001 \\
\hline \multirow[t]{4}{*}{ Test critical values: } & $1 \%$ level & -3.432692 & \\
\hline & $5 \%$ level & -2.862461 & \\
\hline & $10 \%$ level & -2.567305 & \\
\hline & \multicolumn{3}{|c|}{ *MacKinnon (1996) one-sided p-values } \\
\hline
\end{tabular}

(Source: Data processing using EViews 8 software) 
The autocorrelation test in this study was conducted using the Breusch Godfrey test (LM test). The Breusch-Godfrey test results show that the probability value of the LM test is 0.2780 which is greater than $=5 \%$. A probability value greater than $5 \%$ indicates that the data does not have autocorrelation.

White's test results show that the value of Obs r-squared is 56.67501, with a probability value of 0.000000 . The probability value that is smaller than the significance level of $=5 \%$ indicates that the null hypothesis of homoscedastic is rejected, and the residual hypothesis of heteroscedastic is accepted. The following are White's test results:

Table 5

Heteroscedasticity Test

\begin{tabular}{|c|c|c|c|}
\hline \multicolumn{4}{|c|}{ Heteroscedasticity Test: White } \\
\hline F-statistic & 7.218279 & F Prob. (8.2570) & 0.0000 \\
\hline Obs*R-squared & 56.67501 & Chi-Square Prob. (8) & 0.0000 \\
\hline Scaled Explained SS & 173.6067 & Chi-Square Prob. (8) & 0.0000 \\
\hline
\end{tabular}

(Source: Data processing using EViews 8 software)

The ARCH-LM test is used to find the level of ARCH (q) that can be used to model the conditional variance. In Table 6 , it can be seen that the probability value at lag 1 is smaller than the significance level $=5 \%$, meaning that there are ARCH elements up to lag 1 ( $\mathrm{H}_{0}$ is rejected). Therefore, the GARCH $(p, q)$ model used is GARCH $(1,1)$.

Table 6

\section{ARCH-LM Test}

\begin{tabular}{llll}
\hline Heteroscedasticity Test: ARCH & & \\
\hline F-statistic & 157.8989 & F Prob. (1.2576) & 0.0000 \\
Obs*R-squared & 148.8948 & Chi-Square Prob. (1) & 0.0000 \\
\hline
\end{tabular}

(Source: Data processing using EViews 8 software)

Hypothesis testing of the effect of Ramadan month on stock returns was carried out using the GARCH $(1,1)$ model by adding the Ramadan dummy variable to be included in the regression equation. The following are the GARCH $(1,1)$ regression test results:

\section{Table 7}

GARCH $(1,1)$ Regression Test

DEPENDENT VARIABLE: STOCK RETURN METHOD: ML-ARCH (Marquardt)-Normal Distribution

\begin{tabular}{llllll}
\hline Variable & Coefficient & Std. Error & z- statistic & prob. & Hipotesis \\
Mean Equaticn & & & & & \\
C & 0.00006 & 0.000111 & 0.55855 & 0.5765 & \\
WORLD & 0.522499 & 0.069377 & 7.531335 & $0.0000 * * *$ & \\
WORLDLAGl & -0.163637 & 0.074072 & -2.209174 & $0.0272^{* * *}$ & \\
DRAMADHAN & 0.001382 & 0.000346 & 3.996571 & $0.0001^{* * *}$ & Positif \\
\hline
\end{tabular}


(Cont.)

\begin{tabular}{lllll}
\hline \multicolumn{5}{c}{ Variance Equation } \\
\hline $\mathrm{C}$ & 0.00000369 & 0.000000451 & 8.199797 & $0.0000 * * *$ \\
RESID(-1)^2 & 0.195321 & 0.015919 & 12.27006 & $0.0000^{* * *}$ \\
GAR.CH(-!) & 0.722395 & 0.02206 & 32.74677 & $0.0000 * * *$ \\
R.-squared & 0.024782 & & & \\
Adjusted R.- & 0.023646 & & \\
squared & & & \\
Durbin-Watson & 1.946472 & & \\
stat & & & \\
Note: * & $:$ significance at 10\% & \\
& $* * \quad$ significance at 5\% & & \\
& $* * * \quad:$ significance at $1 \%$ & &
\end{tabular}

(Source: Data processing using EViews 8 software)

Stock Return $=0.00006+0.522499$. WORLD -0.163637. WORLDLAG $1+$ 0.001382.DRAMADAN

$\mathrm{GARCH}=0.00000369+0.195321 . \operatorname{RESID}(-1)^{\wedge} 2+0.722395 . \mathrm{GARCH}(-1)$

Linear regression was used to test volatility during Ramadan. Testing volatility cannot use the GARCH $(\mathrm{p}, \mathrm{q})$ regression model because the residual reflects changes in the worldlag1variable, and the variable affects stock returns (dependent variable). Meanwhile, the volatility variable is calculated from the standard deviation of return so that volatility cannot use the GARCH (p,q) model.

The Chow test results show the probability value for the cross-section $\mathrm{F}=$ 0.0000 (for the dependent variable of volatility), which is less than 0.05 . Thus, it can be stated with a $95 \%$ confidence level that the fixed effect model is better than the common effect/PLS model. However, the probability value of cross-section and random period (for the dependent variable volatility) is 1.0000 , which is greater than 0.05 . Thus, it can be concluded that the random effect model is better than the fixed effect model. Table 8 exhibits the regression equation results with volatility (VOL) as the dependent variable, world \& worldlag1 as the control variables, and DRamadan as the independent variable.

Table 8

Regression Test with Random Effect Model (volatility) Results

\begin{tabular}{lrrrrr}
\hline Variable & Coefficient & Std. Error & \multicolumn{1}{c}{ t-Statistic } & \multicolumn{1}{l}{ Prob. } & Hypothesis \\
\hline C & 0.017534 & 0.001556 & 11.27154 & 0.0000 & \\
WORLD & 0.860764 & 0.202738 & 4.245694 & $0.0000^{* * *}$ & \\
WORLDLAG1 & 0.402735 & 0.195331 & 2.061808 & $0.0393^{* *}$ & \\
DRAMADAN & -0.001683 & 0.001624 & -1.036459 & 0.3001 & Positive \\
R-squared & 0.014279 & & & & \\
$\begin{array}{l}\text { Adjusted R- } \\
\text { squared }\end{array}$ & 0.013132 & & & & \\
\hline
\end{tabular}


(Cont.)

\begin{tabular}{ll}
\hline F-statistic & 12.438930 \\
Prob(F-statistic) & 0.000000 \\
\hline Note: $*$ & $:$ significance at $10 \%$ \\
& $* * \quad:$ significance at $5 \%$ \\
& $* * * \quad:$ significance at $1 \%$
\end{tabular}

(Source: Data processing using EViews 8 software)

\section{Volatility $=0.017534+0.860764$. WORLD +0.402735. WORLDLAG1 - 0.001683.DRAMADAN}

A z-test is a statistical test whose hypothesis testing is approximated with a normal distribution. In Table 7 , it can be seen that the world variable has a positive value with a significance level of 0.0000 . This signifies that when world return increases, ISSI return will increase. Thus, the world has a significant positive effect on stock returns.

The worldlag1 variable has a negative value with a significance level of 0.0272. This negative sign implies that when the world returns at lag 1 increase, the stock return will decrease. Thus, the worldlag1 variable has a significant negative effect on stock returns.

The DRamadan variable (Ramadan dummy) has a positive value with a significance level of 0.0001. Meanwhile, the non-Ramadan coefficient (C) has a positive value with a significance level of 0.5765 . Thus, the stock return during Ramadan is significantly higher than non-Ramadan months.

A t-test is a statistical test used to test the relationship between the independent and dependent variables partially. Table 8 is a linear regression equation with volatility as the dependent variable; it can be seen that the world variable has a positive value with a significance level of 0.0000 . This signifies that when world volatility increases, stock volatility will increase. Thus, world volatility has a significant positive effect on volatility.

The worldlag1 variable has a positive value with a significance level of 0.0393 . This signifies that when worldlag1 volatility increases, stock volatility will increase. Thus, worldlag1 volatility has a significant positive effect on volatility.

The DRamadan variable has a negative value with a significance level of 0.3001 . Meanwhile, the probability value of the non-Ramadan coefficient $(\mathrm{C})$ is 0.0000 . The significance value of the DRamadan variable is greater than $10 \%$ (significance requirements are $1 \%, 5 \%$, and $10 \%$ ). Thus, Ramadan has a negative effect.

An F-test aims to determine whether the independent variables have an effect on the dependent variable. The F-test results can be seen from the probability value of the F-statistic. If the value is getting smaller, it means that the influence of the independent variable on the dependent variable is getting stronger.

The authors used confidence intervals of $99 \%, 95 \%$, and $90 \%$ or significance level $(\alpha)=1 \%, 5 \%$, and $10 \%$. From Table 8 , it can be seen that the probability value of the F-statistic is $0.0000 \%$, which is less than $1 \%$. Thus, it can be stated that the world, worldlag1, and DRamadan variables have a significant effect on 
stock volatility at the $1 \%$ level, so the independent variables in this study can be used to estimate the dependent variable properly.

The coefficient of determination serves to show how much the independent variable can explain the dependent variable. In Table 7, the R2 and adjusted R2 are 0.24782 and 0.023646 , and in Table 8, the R2 and adjusted R2 are 0.014279 and 0.013132 .

The study results show that the world variable has a positive and significant effect on returns of stocks included in the ISSI index (Indonesian Sharia Stock Index) over the period 15 November 2012 - 20 September 2017 (1434-1438H). This finding is in line with Bialkowski et al. (2012), Al-Ississ (2015), and AlKhazali et al. (2017). This significant positive effect can be explained by AlKhazali et al.'s (2017) study that stipulates the world variable is positive and significant, indicating that the stock market being studied has its stock price movement affected by global issues. Global issues affect stock price movement because foreign investors still dominate securities ownership in the Indonesian capital market.

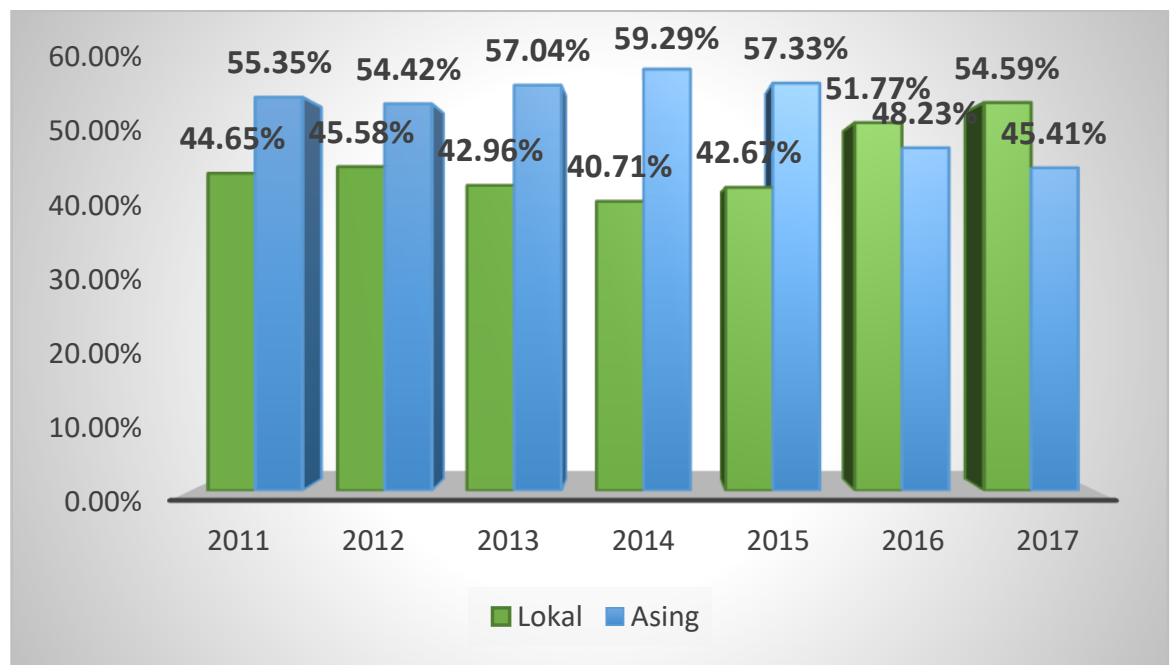

Figure 2

Foreign vs. Local Investor Ownership Chart

(Source: KSEI, 2018)

The results show that the worldlag1 variable has a negative but significant effect on stock returns. This finding contradicts the study conducted by Bialkowski et al. (2012) and Al-Khazali et al. (2017), who posit that worldlag1 return has a positive and significant effect on stock returns.

The results show that the DRamadan variable (Ramadan dummy) has a positive and significant effect on returns of stocks included in the ISSI (Indonesian Sharia Stock Index) index over the period 15 November 2012 - 20 September 2017 (1434-1438H). The DRamadan coefficient, which is greater than the constant-coefficient (non-Ramadan) of 0.00004, indicates that returns during Ramadan are higher than other months (non-Ramadan). Thus, Ramadan affects the returns of stocks included in the ISSI index (Indonesian Sharia Stock Index) over the period 15 November 2012 - 20 September 2017 (1434-1438H). This 
finding is in line with Oguzsoy \& Guven (2004), Al-Hajieh et al. (2011), Bialkowski et al. (2012) and Wasiuzzaman \& Al-Musehel (2017), but contrary to research conducted by Al-Ississ (2015), Al-Khazali et al. (2017), and Lai \& Windawati (2017).

Positive stock returns during Ramadan are caused by investors who tend to earn profits on overvalued stocks during Ramadan month. Additionally, during Ramadan, investors try to avoid risk by making transactions in overvalued stocks so that investors reduce transaction risk. Investors will hold undervalued stocks to avoid losses. Investors have confidence and optimism that undervalued stocks will increase in value in the future. According to Bialkowski et al. (2012), during Ramadan, Muslims teach empathy, share with unlucky people, and increases worship activities; thus, it will improve their social sense and mood. A positive mood will make investors more optimistic (Gavrilidis et al., 2016). As a result, according to Rosen \& Wu (2004) in Sonjaya \& Wahyudi (2016), it will affect stock valuations in the market.

The results show that the world variable has a significant positive effect on the volatility of stocks included in the ISSI index (Indonesian Sharia Stock Index) over the period 15 November 2012 - 20 September 2017 (1434-1438H). The positive and significant world variable indicates that the stock market being studied has its stock price movement affected by global issues. Global issues affect stock price movement because foreign investors still dominate securities ownership in the Indonesian capital market.

The results show that the worldlag1 variable has a positive and significant effect on the volatility of stocks included in the ISSI index (Indonesian Sharia Stock Index) over the period 15 November 2012 - 20 September 2017 (14341438H).

The results show that the Ramadan dummy variable has a negative and insignificant effect on the volatility of stocks included in the ISSI index (Indonesian Sharia Stock Index) over the period 15 November 2012 - 20 September 2017 (1434-1438H). In addition, the constant coefficient (nonRamadan) is 0.017214 , which is greater than the DRamadan coefficient, meaning that there is no significant difference in volatility between Ramadan and nonRamadan months. These results are supported by Husain (1998) but contrary to Al-Khazali et al. (2017), Wasiuzzaman \& Al-Musehel (2017), and Lai \& Windawati (2017).

According to Al-Khazali et al. (2017), the decrease in volatility during Ramadan month is caused by two reasons. First, some Muslim communities consider trading on a speculative basis because this is a form of gambling prohibited in Islam. Second, some Muslim investors will minimize their trading activities using debt (margin trading) because the strict prohibition against the use of interest or Riba.

\section{CONCLUSION}

Based on the z-test, it is concluded that the world return variable has a positive and significant effect on stock returns. The worldlag1 variable has a negative but significant effect on stock returns. The DRamadan variable (Dummy Ramadan) 
has a positive and significant effect on stock returns. While, based on the F-test, it is found that the results of statistical calculations for the dependent variable volatility show that the calculated $\mathrm{F}$ is 12.438930 with a probability of 0.00000 $<0.05$. This shows that the world, worldlag1, and DRamadan variables have a significant effect on volatility. Based on the results of hypothesis testing using the t-test, the results show that the world variable has a positive and significant effect on volatility. The worldlag1 variable has a positive but not significant effect on volatility. The DRamadan variable has a negative and insignificant effect on volatility.

The R2 and adjusted- R2 are 0.024782 and 0.023646 on the dependent variable of stock return. Thus, the coefficient of determination of adjusted R2 is 0.023646 on the dependent variable of stock return. This coefficient means that changes in the stock return variable can be explained by the world, worldlag1, and DRamadan variables of 2.36\%. Meanwhile, the values of R2 and adjusted R2 on the dependent variable of volatility (volatility) are 0.014279 and 0.013132 . This coefficient means that changes in the volatility variable (volatility) can be explained by the world, worldlag1, and DRamadan variables of $1.31 \%$.

This study can be used as a recommendation for investors to buy stocks before Ramadan month because this study reveals that the stock returns produced during Ramadan are positive so that the price will increase compared to nonRamadan months. In addition, investors can use the results of this study as a basis to make investment decisions in countries that have a majority Muslim population.

This study can be used as a reference to develop further study, where it would be better if the study is conducted using all stocks listed on the Indonesian stock exchange (IDX), both Islamic and non-Sharia stocks. In addition, the study object can be expanded in terms of the study period and other developing countries so that the effect of Ramadan on stock returns and volatility can be predicted and generalized better. In further research, the world variable can use the Dow Jones index because investors in the Indonesian capital market respect the index more than the MSCI index.

\section{REFERENCES}

Al-Ississ, M. (2015), The Holy Day Effect, Journal of Behavioral and Experimental Finance, 5, March, 60-80.

Al-Ississ, M. (2010), The Impact of Religious Experience on Financial Markets. Working Paper. Harvard Kennedy School of Government.

Al-Hajieh, H., Redhead, K., and Rodgers, T. (2011), Investor Sentiment and Calendar Anomaly Effects: A Case Study of the Impact of Ramadan on Islamic Middle Eastern Markets, Research in International Business and Finance, 25 (3), 345-356.

Al-Khazali, O., Bouri, E., Roubaud, D., \& Zoubi, T. (2017), The Impact of Religious Practice on Stock Returns and Volatility, International Review of Financial Analysis, 52, July, 172-189. 
Annila, N. \& Kristanti, F.T. (2015), Model GARCH (Generalized Autoregressive Conditional Heteroscedasticity) Untuk Prediksi dan Akurasi Harga Saham Masa Depan, e-Proceeding of Management, 2(1), 255-266.

Bialkowski, J., Etebari, A., and Wisniewski, T.P. (2012), Fast Profits: Investor Sentiment and Stock Returns during Ramadan, Journal of Banking \& Finance,36 (3), 835-845.

Gavrilidis, K., Kallinterakis, V., and Tsalavoutas, I. (2016), Investor Mood, Herding and the Ramadan Effect, Journal of Economic Behavior and Organization, 132 (supplement), 23-28.

Habib bin Hilal. (n.d), Kalender Islam, https://www.al-habib.info/kalender-islam/

Husain, F. (1998), A Seasonality in the Pakistan Equity Market: the Ramadan Effect, The Pakistan Development Review, 37(1), 77 - 81.

KSEI. (2018), Unduh Kepemilikan Efek, https://www.ksei.co.id /archive_download/holding_composition

Lai, Y., \& Windawati. A. (2017), Risk, Return and Liquidity during Ramadan: Evidence from Indonesian and Malaysian Stock Markets, Research in International Busines and Finance, 42(December), 233-241.

Oguzsoy, C.B., and Guven, S. (2004), Holy Days Effect on Istanbul Stock Exchange. Journal of Emerging Market Finance, 3(1), 63-75.

Sonjaya, A.R., \& Wahudi. I. (2016), The Ramadan Effect: Illusion or Reality?, Arab Economic and Business Journal, 11(1), 55-71.

Wasiuzzaman, S., \& Al-Musehel, N.A. (2017), Mood, Religious Experience and the Ramadan Effect, International Journal of Emerging Markets, 13(1), 290307. 